\title{
Global educational trends in intellectual capital development
}

\author{
Svetlana Ashmarina ${ }^{1}$,Elena Kandrashina ${ }^{1 *}$, Anna Zotova ${ }^{1 *}$ \\ ${ }^{1}$ Samara State University of Economics, Russia, 443090, Samara, Sovetskoi Armii Street, 141
}

\begin{abstract}
Modern "post-industrial" era is distinguished by such rapid global changes and almost instantaneous copying of products and services that make it meaningless reaching the goal of long-term retention of a certain market position. The strategy ceased to be only a long-term plan and was formed as the concept of a management process which is characterized by a constant adjustment in the on-line regime. Today, the educational community is also subjected to these changes. Universities today are doing their best to attract international students. They are mobile young people (there are more than 5 million people in the world), possessing great abilities. The war for talent leads to the rapid differentiation of educational institutions. Technological innovations came with a delay of about 10 years in the sphere of education. Today, the annual growth of the online education market is $27 \%$, the traditional - $5 \%$. In 2016, more than 50 million people around the world studied using the largest online platforms. So the main task of this research work is to define the influence of some educational global trends on intellectual capital development in the frame of high education system and assess the readiness of Russian universities to such influence.
\end{abstract}

Key words: global educational trends, universities, e-learning

\section{Introduction}

The modern "post-industrial" era is distinguished by such rapid global changes and almost instantaneous copying of products and services that make it meaningless to make the goal of long-term retention of a certain market position to be the absolute one. Constant perfection of design and service accompanying the provision of products and services, becomes a condition for successful business development. The strategy ceased to be only a long-term plan and was formed as a concept of a management process characterized by a constant adjustment in the on-line regime. Today, the educational community is also subjected to these changes. Universities, educational consortia and entire countries are doing their best to attract international students. These are mobile young people (there are more than 5 million people in the world), possessing great abilities. The war for talent leads to rapid differentiation of educational institutions. The appearance in the early 2000s of international university rankings (ARWU, QS, THE) gave us the opportunity to compare universities of different countries, which was the beginning of global competition era. The

*Corresponding authors: elka@mail.ru, azotova@mail.ru 
ratings have launched new mechanisms for the redistribution of resources in education: leaders strengthen their reputation, receive funding. Academic mobility is also in the best hands: according to research, masters, graduate students and professors today choose universities on the basis of international ratings. The wall has grown between high schools of the top 100 and all the others and this inequality will grow rapidly with each passing year. As a result, a country that does not have universities in a group of leaders, in the long term, 5-10 years, risks losing competition for intellectual capital and becoming an educational province [1].

\section{Methods and Results}

\subsection{The analysis of trends stimulating education system changes and intellectual capital development}

The basic changes are based on three key preconditions:

- digital revolution

- demographic trends

- $\quad$ fastening speed of social development

Table 1. Educational trends and their influence on high education system

\begin{tabular}{|c|c|c|c|}
\hline $\begin{array}{l}\text { Megatrends (global } \\
\text { trends, influencing all } \\
\text { human spheres) }[2,3]\end{array}$ & $\begin{array}{l}\text { Trends, influencing } \\
\text { education system }\end{array}$ & $\begin{array}{l}\text { First level reaction } \\
\text { (the result, which is } \\
\text { the output of trend } \\
\text { influence on } \\
\text { education system) }\end{array}$ & $\begin{array}{l}\text { Second level } \\
\text { reaction (the } \\
\text { reaction on the first } \\
\text { level result) }\end{array}$ \\
\hline \multirow{3}{*}{$\begin{array}{l}\text { 1. Information } \\
\text { technologies } \\
\text { development }\end{array}$} & Education virtualization & $\begin{array}{l}\text { - Emergence and } \\
\text { development of new } \\
\text { forms and approaches } \\
\text { to education based on } \\
\text { modern technologies } \\
\text { usage. } \\
\text { - Competition growth } \\
\text { in the sphere of } \\
\text { virtual (distance) } \\
\text { education. }\end{array}$ & $\begin{array}{l}\text { - New approaches to } \\
\text { distance education } \\
\text { implementation. } \\
\text { - Education quality } \\
\text { decrease. }\end{array}$ \\
\hline & $\begin{array}{l}\text { Personification, } \\
\text { individualization }\end{array}$ & $\begin{array}{c}\text { - E-learning education } \\
\text { technology } \\
\text { popularization, } \\
\text { teaching on-line. }\end{array}$ & $\begin{array}{l}\text { - Growth in the gap } \\
\text { in the quality of } \\
\text { students education. }\end{array}$ \\
\hline & Gamefication & $\begin{array}{l}\text { - Growth of education } \\
\text { projects based on } \\
\text { gamefication elements. }\end{array}$ & $\begin{array}{c}\text { - Emergence of new } \\
\text { education programs } \\
\text { based on } \\
\text { gamefication. }\end{array}$ \\
\hline $\begin{array}{l}\text { 2. Demographic } \\
\text { trend }\end{array}$ & $\begin{array}{c}\text { Demographic crisis in } \\
\text { Russia }\end{array}$ & $\begin{array}{l}\text { - The decrease in the } \\
\text { number of students } \\
\text { under the influence of } \\
\text { such factors: } \\
\text { demography, the rise } \\
\text { of examination } \\
\text { entrance mark, the } \\
\text { education fee, the } \\
\text { decrease in the places } \\
\text { granted by federal or }\end{array}$ & $\begin{array}{l}\text { - The growth in the } \\
\text { struggle for school } \\
\text { leavers, competition } \\
\text { rise. } \\
\text { - Development of } \\
\text { education programs } \\
\text { aimed at adults } \\
\text { learning. } \\
\text { - Development of } \\
\text { academic mobility. }\end{array}$ \\
\hline
\end{tabular}




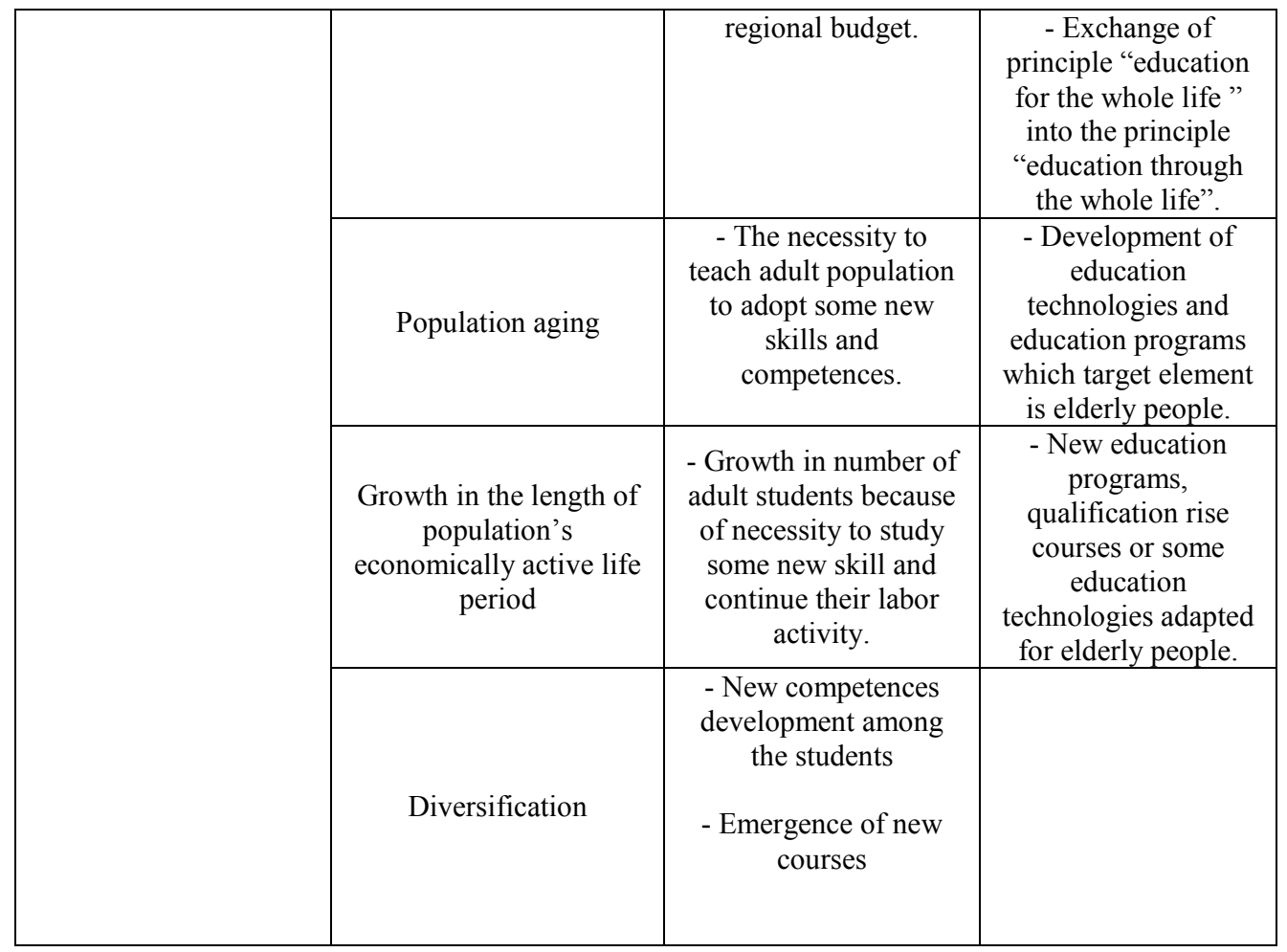

In the sphere of education, technological innovations came with delay of about 10 years. The first online projects here appeared in the 1990s and were associated with the transfer of electronic materials to educational materials. True, they did not have a serious impact on the industry. In 2011, second-generation projects appeared on the market - mass open online courses (Massive Open Online Courses, or MOOC). It is believed that it was the point from which the digital revolution began in education.

Today, the annual growth of the online education market is $27 \%$, the traditional $-5 \%$. In 2016, more than 50 million people around the world studied using the largest online platforms (EdX, Coursera, Udacity, etc.), 800 thousand of them are Russians. In addition to private projects, a number of states launched their own national platforms - the United Kingdom, Australia, Brazil, and Russia joined to the countries in 2015. The main innovation of such platforms is the design of the courses: they consist of small video fragments for 5-10 minutes, due to which the listeners kept concentration. 2015 was a new milestone in the development of digital education. LinkedIn for $\$ 1.5$ billion bought the project Lynda.com, which revised the training process. The basis of the program was not mini-lectures, but tutorials, short video instructions for representatives of different professions. For several years, the world's leading experts have created more than 25 thousand tutorials, and for access to them it is enough to buy a monthly, semi-annual or annual subscription. There was a new type of educational project - a kind of "intellectual fitness room", where at any time you can buy a ticket.

The development of information technology entailed a boom of educational startups. Since the beginning of the 2000s, a new class of projects has appeared in the field of education. For the first time significant financial resources were attracted not by universities with their centuries of history and brand, but young teams of entrepreneurs. Ten years ago, the global volume of venture investments in educational startups barely reached 
\$ 100 million, and in 2016 it exceeded \$ 3 billion, which is comparable to the annual costs of education of individual countries.

Profiles of educational startups are diverse. For example, the most successful start-up, attracted more than $\$ 300$ million, - TutorGroup - teaches English on the Internet. And the project Achieve3000, which collected a quarter of a billion dollars, develops the ability to read and understand the text. One of the most vivid examples of the new era is the Minerva program, which claims to train world leaders and innovators of the future. Its founders managed to attract more than $\$ 25$ million at the idea stage.

All new educational projects unite one thing - they are built on modern technologies, use a synthesis of advanced developments in the field of computer intelligence, digital technologies and behavioral psychology. The best educational startups already compete with traditional universities for their investments and talents.

The demographic megatrend appears as a trend towards a change in the population on a global scale [4].

In different countries, this trend has a different focus. In countries such as China, India, Pakistan, etc. the population is growing. The opposite situation is observed in Russia.

The main reactions of Russian education system to this trend are:

- Decrease in the number of students under the influence of the demographic factor;

- Population aging (demographic aging) is the result of long-term demographic changes, changes in the nature of population reproduction, fertility, mortality their ratio, and also partly migration. The main reaction of the education system to this trend is the emergence of the need to educate people of the older generation with new skills and competences, which ultimately leads to the development of teaching technologies and educational programs whose target segment is older generation. Another social trend that manifests itself in lengthening the life expectancy of people leading an active economic life, engaged in production, participating in economic processes can be referred to as "increasing the duration of active economic life of the population." The main reaction of Russian education system to this trend is an increase in the proportion of adult students and students in the education system, due to the need for skills and competencies to continue working. This trend is also triggered by another factor associated with the new industrial revolution and the emergence of new professions.

New technologies are causing "industrial revolutions" that change the work of companies. Business dictates new requirements to people's competencies and the speed at which they are received.

There is a number of "retired professions" leaving the market. The most striking example of recent years is the massive bankruptcies of travel agencies, losing competition to services like Booking.com or Airbnb. At the same time, thanks to new technologies, the professions of the future appear, in which intellectual skills and qualities, which help to make non-standard decisions, are in demand.

Today it is already impossible to build a successful professional trajectory for years to come, but the traditional education system is based on the principle of long-term planning. The list of the most popular competences will be updated more often. If earlier a new profession arose once in 20-30 years, today it is every 3-5 years. The ability of the education system to respond quickly to new requests, to train specialists not for 5 years, but for 5 months, becomes a condition for the country's competitiveness. To this challenge, most educational institutions in the world have only to find an answer [5].

In addition, the demographic trend associated with the aging of the population in Russia also contributes to the development of online platforms. To actively use such educational products, young people often lack internal motivation and self-organization. Students who receive basic education at the first level often need that external formal shell, which is 
created by the traditional approach to learning: attending classrooms, the presence of formal, and not virtual control points.

For an adult, all these external attributes of learning are no longer necessary, his main driver is the desire to get the necessary knowledge and this inner motivation makes him a more stable consumer of online courses.

All these trends, as well as the growing demand for the practicality of scientific research and the rapid commercialization of results by erasing the "science-practice" boundary, forced the RF Government to begin implementing the State Program of the Russian Federation "Development of Education" for 2013-2020, which will lead to an increase in the role of corporate training, to a closer connection of vocational education with the subjects of demand in the labor market. By 2020, all students will study according to individual curricula, which include a significant proportion of independent work using information technology.

\subsection{The analysis of distance learning development in high education system of Samara region.}

The most modern trend in the development of modern higher education is the promotion of distance learning and the gradual replacement of distance education by distance education. To effectively promote the distance education system, the development of information and communication technologies is vital. The authors of this work analyzed distance learning technologies in the leading universities of the Samara region (Table 1.) The results of the authors' research showed that a number of Samara higher educational institutions have already demonstrated high readiness for the projected changes and are actively implementing information and communication technologies. The largest number of areas covered by distance education is shown by the Samara State Technical University. Individual universities are still lagging far behind in promoting distance education with the help of modern technologies. 
Table 2. Types of distance education technologies used in the HEIs of Samara region

\begin{tabular}{|c|c|c|c|}
\hline $\begin{array}{c}\text { The title of the } \\
\text { university }\end{array}$ & $\begin{array}{c}\text { Separate courses } \\
\text { may be studied by } \\
\text { distance education } \\
\text { technologies }\end{array}$ & $\begin{array}{c}\text { The ability to get } \\
\text { distance degree at } \\
\text { some programs }\end{array}$ & $\begin{array}{c}\text { The ability to get the } \\
\text { second degree by } \\
\text { distance technologies }\end{array}$ \\
\hline $\begin{array}{c}\text { Volga region state } \\
\text { university of } \\
\text { telecommunication and } \\
\text { information technologies }\end{array}$ & + & - & - \\
\hline $\begin{array}{c}\text { Samara region academy } \\
\text { of Nayanova }\end{array}$ & + & + & - \\
\hline $\begin{array}{c}\text { Samara University } \\
\text { Samara State Agricultural } \\
\text { Academy }\end{array}$ & + & - & - \\
\hline $\begin{array}{c}\text { Samara State technical } \\
\text { University }\end{array}$ & + & - & + \\
\hline $\begin{array}{c}\text { Samara State Transport } \\
\text { University }\end{array}$ & + & + & - \\
\hline $\begin{array}{c}\text { Samara State Medical } \\
\text { University }\end{array}$ & + & - & - \\
\hline $\begin{array}{c}\text { Samara State University } \\
\text { of Economics }\end{array}$ & + & - & - \\
\hline $\begin{array}{c}\text { Samara branch «Moscow } \\
\text { City Pedagogical } \\
\text { University» }\end{array}$ & + & + & - \\
\hline
\end{tabular}

Samara State Economic University launched the site "Virtual Campus", but so far only for students of the Master degree faculty. This site was organized on the basis of the MOODLE platform, which is a content management system (CMS), specifically designed to create qualitative online courses by teachers.

As a result of the research, the greatest activity of non-state educational institutions and branches in the promotion of their distance programs was revealed. These educational institutions quite reasonably seek to occupy that segment of the market of educational services, which is not yet being interested too much by the key universities in the region. So in the Samara branch of the Moscow City Pedagogical University, the specialized structural subdivision - the center for distance learning was allocated. Also, a program was developed to implement distance learning based on the distance education system "Prometheus".

\section{Conclusion}

An analysis of the results of studies on the use of information and communication technologies in higher education suggests that there are no general concepts that would allow us to capture and present a multitude of facts accumulated in the practice of education and upbringing in a single system of concepts. The analysis of practice also allows us to conclude that there is an underestimation of the possibilities of ICT in the sphere of domestic higher education. This is primarily due to the complexity and low readiness of higher education institutions to introduce and use information and communication technologies in their activities. 
The research is done in the frame of the state task of the Ministry of Education and Science of the Russian Federation №26.9402017/PC "Change management in high education system on the basis of sustainable development and interest agreement".

\section{References}

1. The report of world economic forum Redesigning Business Value \& A Roadmap to Sustainable Consupmtion, [online], Available at: http://www3.weforum.org/docs/WEF_RedesigningBusinessValue_SustainableConsum ption_Report_2010.pdf (2010)

2. J. Neisbitt, P. Aburdene, Megatrends 2000: Ten New Directions for the 1990s, $1^{\text {st }}$ ed.,William \& Morrow Company, Inc., 384 p. (1990)

3. T.A. Shakleina, A. A. Baikova, Megatrends: Main evolution trends of global character in XXI century, Moscow, Aspekt Press, 448 p. (2014)

4. R. R Khasiev, Forecasting of demographic situation in the Russian Federation. Science Symbol, 12-1, (2015)

5. G. R. Khasaev, S. I. Ahmarina, Main trends and perspectives of HEIs competitiveness improvement. Vestnik SSEU, 8(118), 62-65 (2014) 
